\title{
The Comfort Map-A Possible Tool for Increasing Personal Comfort in Office Workplaces
}

\author{
Ágnes Borsos ${ }^{1, *(D)}$, Erzsébet Szeréna Zoltán ${ }^{2} \mathbb{D}$, Éva Pozsgai ${ }^{3}$, Balázs Cakó ${ }^{4}$, Gabriella Medvegy ${ }^{1}$ \\ and János Girán ${ }^{5}$ (D)
}

1 Department of Interior, Applied and Creative Design, Faculty of Engineering and Information Technology, University of Pécs, Boszorkány út 2, H-7624 Pécs, Hungary; medvegygabriella@mik.pte.hu

2 Department of Architecture and Urban Planning, Faculty of Engineering and Information Technology, University of Pécs, Boszorkány út 2, H-7624 Pécs, Hungary; betty.zoltan@mik.pte.hu

3 Institute of Primary Health Care, Medical School, University of Pécs, Rákóczi Street 2, H-7623 Pécs, Hungary; pozsgai.eva@pte.hu

4 Department of Building Services and Building Engineering, Faculty of Engineering and Information Technology, University of Pécs, Boszorkány út 2, H-7624 Pécs, Hungary; cako.balazs@mik.pte.hu

5 Department of Public Health, Medical School, University of Pécs, Szigeti u. 12, H-7624 Pécs, Hungary; janos.giran@aok.pte.hu

* Correspondence: borsos.agnes@mik.pte.hu; Tel.: +36-304-211-256

Citation: Borsos, Á.; Zoltán, E.S.; Pozsgai, É.; Cakó, B.; Medvegy, G.; Girán, J. The Comfort Map-A

Possible Tool for Increasing Personal Comfort in Office Workplaces. Buildings 2021, 11, 233. https:// doi.org/10.3390/buildings11060233

Academic Editors: Giulia Lamberti and Derek Clements-Croome

Received: 14 April 2021

Accepted: 26 May 2021

Published: 29 May 2021

Publisher's Note: MDPI stays neutra with regard to jurisdictional claims in published maps and institutional affiliations.

Copyright: (c) 2021 by the authors. Licensee MDPI, Basel, Switzerland. This article is an open access article distributed under the terms and conditions of the Creative Commons Attribution (CC BY) license (https:// creativecommons.org/licenses/by/ $4.0 /)$.
Abstract: Previous studies have shown that indoor environmental quality (IEQ) parameters may have a considerable effect on office employees' comfort, health and performance. Therefore, we initiated a research program to help occupants identify IEQ parameters they perceive as risk factors for their health in an office and enhance their comfort levels in an office environment. Since we assumed that office employees might have different indoor environmental quality expectations related to their work area and that these differences could be measured, our objective was to develop an office 'comfort map' based on occupants' individual IEQ preferences. Thus, the goal of the comfort map would be to help tailor office spaces to their occupants' health and comfort expectations. The comfort survey was developed to assess the comfort-related opinions of the occupants, based on IEQ parameters (visual comfort, acoustic comfort, air quality and thermal comfort) of a chosen open-plan office building. The survey also assessed the degree to which the given IEQ parameter was considered a health risk factor by occupants or caused a negative comfort sensation for them. The survey was filled in by 216 occupants. The answers were then analyzed with the help of a frequency table depicting relative frequency. The measurements of IEQ parameters took place in an openplan office in the chosen office building (a Hungarian subsidiary's office building belonging to an international company in Budapest). The occupants had different opinions regarding the perceived effects of the IEQ parameters on their health and comfort. Almost two-thirds of the respondents $(64.8 \%)$ were dissatisfied with the adjustability of the noises and sounds IEQ parameter at their workstation. Furthermore, half of the respondents (50.1\%) were dissatisfied with the adjustability of ventilation. Most of the occupants (45.8\%) considered noises and sounds as the IEQ parameter that had a negative effect on their health. There were also IEQ differences between different areas of the office space. Based on these results, a comfort map was developed for the office. The comfort map contains information about the IEQ characteristics of each workstation by depicting the thermal comfort, carbon dioxide, visual comfort and acoustic comfort characteristics of a given workstation on a relative scale. Based on the thermal, air, acoustic, and lighting differences between the workstations, occupants can select their preferred workstations when a desk-sharing system works. Although still in its pilot phase, the comfort map could increase the chances for office employees to find the workstation best suited to their IEQ expectations. This could improve occupants' overall comfort level, which could in turn enhance occupants' productivity and mental as well as physical health.

Keywords: exploratory research; indoor environment quality; multidisciplinary approach; workplace health and wellbeing 


\section{Introduction}

Personal comfort-related issues deserve special attention in office workplaces. Office workers spend at least $40 \mathrm{~h}$ a week in their workplace and spend $90 \%$ of this time indoors [1] Thus, properties of office spaces such as interior design, size of personal workspace, workstation equipment and furniture ergonomics all determine how comfortable employees feel in the office [2]. However, over the last two decades, research has increasingly shown that - in addition to the physical environment of office spaces-indoor environmental quality (IEQ) parameters such as visual comfort, acoustic comfort, air quality and thermal comfort have a considerable effect on the comfort, health and productivity of employees [3]. Consequently, in this research project, we considered visual comfort (total luminous flux incident on the surface of workstations), acoustic comfort (reverberation time and sound level of the office), air quality ( $\mathrm{CO}_{2}$ concentration and air velocity of workstations) and thermal comfort (air temperature, humidity, radiant temperature of workstations) as the main components of IEQ (see Section 2.5). Although there are many IEQ parameters, those that influence comfort levels due to differences between the physical characteristics of an office building, such as windows, air vents, surfaces and building sitting, are parameters of particular interest [4].

Examining the impact of each comfort parameter on comfort level, it is evident that, besides affecting mood and concentration abilities [5,6], the lighting conditions of an office workplace influence the comfort, mental and physical health, behavior and performance of employees, as has been shown in a previous study [7]. In an open-plan office environment, acoustic disturbances have been demonstrated to have adverse effects on cognitive abilities, such as mental arithmetic tasks [8], correction tasks [9] and understanding text and recall [10], all leading to decreased work performance. Ventilation rates and carbon dioxide concentrations are chiefly responsible for determining air quality in the office space. Ventilation rates of $25 \mathrm{~L} / \mathrm{s} /$ person or above have been associated with reduced prevalence of sick building syndrome (SBS) as well as a lower risk of respiratory diseases [11,12]. Previous research has found that for every additional $250 \mathrm{ppm}$ rise in indoor carbon dioxide concentrations above $800 \mathrm{ppm}$, the odds of sore throats, irritated nose and sinus symptoms and combined mucous membrane symptoms increase by 1.3-2.3 [13]. Continuous carbon dioxide $\left(\mathrm{CO}_{2}\right)$ exposure exceeding $1000 \mathrm{ppm}$ has also been suggested to lead to the impairment of higher-level cognitive abilities [14].

Perhaps one of the most complex parameters of IEQ is thermal comfort. It comprises the effects of air temperature, humidity, air velocity and radiant temperature. Occupants' opinions about thermal comfort are influenced by their clothing and mental and physical status. Therefore, satisfaction with thermal comfort is closely connected with occupants' overall satisfaction with the work environment [15]. However, the importance of thermal comfort is also crucial in terms of health. In most cases, the occurrence of SBS has also been linked to thermal comfort [16].

The parameters of IEQ and their individual adjustability may have a notable impact on occupants' health and comfort. Studies have suggested that office workers who are allowed to control the lighting or temperature in their work area suffer less from SBS than workers who are not granted this opportunity [17]. Many employers are keen to provide an office environment that supports employees' personal comfort levels and to promote their health as much as possible. However, the individual control of IEQ parameters is generally not feasible [18].

In Hungary, the comfort parameters of office workplaces are regulated by a ministerial decree [19]. This regulation is in line with the relevant EU directive [20]. The decree stipulates that office lighting for writing, typing, reading and data processing must be a minimum of 500 lux on average. Furthermore, workstations must provide sufficient quantity and quality of air. The maximum airspeed should be $0.1 \mathrm{~m} / \mathrm{s}$ to prevent uncomfortable and unhealthy air movement. For in-office work, the air temperature must be between $20^{\circ} \mathrm{C}$ to $24^{\circ} \mathrm{C}$ throughout the working day. The sound pressure level in offices should not exceed $60 \mathrm{~dB}$. The controllability of comfort parameters is not a prerequisite for compliance 
with the standards for office workplaces. However, according to the data collected from workers (see Table 1, Figure 1) this aspect is crucial to workers.

Table 1. Occupants' satisfaction with the adjustability of IEQ parameters in their work environment.

\begin{tabular}{|c|c|c|c|c|c|c|}
\hline \multirow[b]{2}{*}{ IEQ Parameters } & \multicolumn{6}{|c|}{ Q22: How Satisfied Are You with the Adjustability of the Following Factors in Your Work Environment? } \\
\hline & $\begin{array}{c}\text { Very Dissatisfied } \\
(\%)\end{array}$ & $\begin{array}{c}\text { Dissatisfied } \\
(\%)\end{array}$ & $\begin{array}{c}\text { Neutral to Me } \\
(\%)\end{array}$ & $\begin{array}{c}\text { Satisfied } \\
(\%)\end{array}$ & $\begin{array}{c}\text { Fully Satisfied } \\
(\%)\end{array}$ & $\begin{array}{c}\text { I Can't Decide } \\
(\%)\end{array}$ \\
\hline Odors $(N=216)$ & 19.9 & 18.1 & 28.7 & 19.4 & 9.7 & 4.2 \\
\hline Ventilation $(N=216)$ & 24.1 & 25.9 & 25.0 & 19.0 & 4.2 & 1.9 \\
\hline Noises and sounds $(N=216)$ & 38.9 & 25.9 & 18.1 & 13.0 & 3.2 & 0.9 \\
\hline Shielding $(N=216)$ & 10.6 & 11.6 & 23.1 & 39.4 & 12.0 & 3.2 \\
\hline Lighting $(N=216)$ & 14.8 & 16.2 & 24.1 & 33.8 & 9.3 & 1.9 \\
\hline Thermal conditions $(N=216)$ & 28.7 & 18.1 & 19.0 & 24.1 & 8.3 & 1.9 \\
\hline
\end{tabular}

Results from primary data collection.

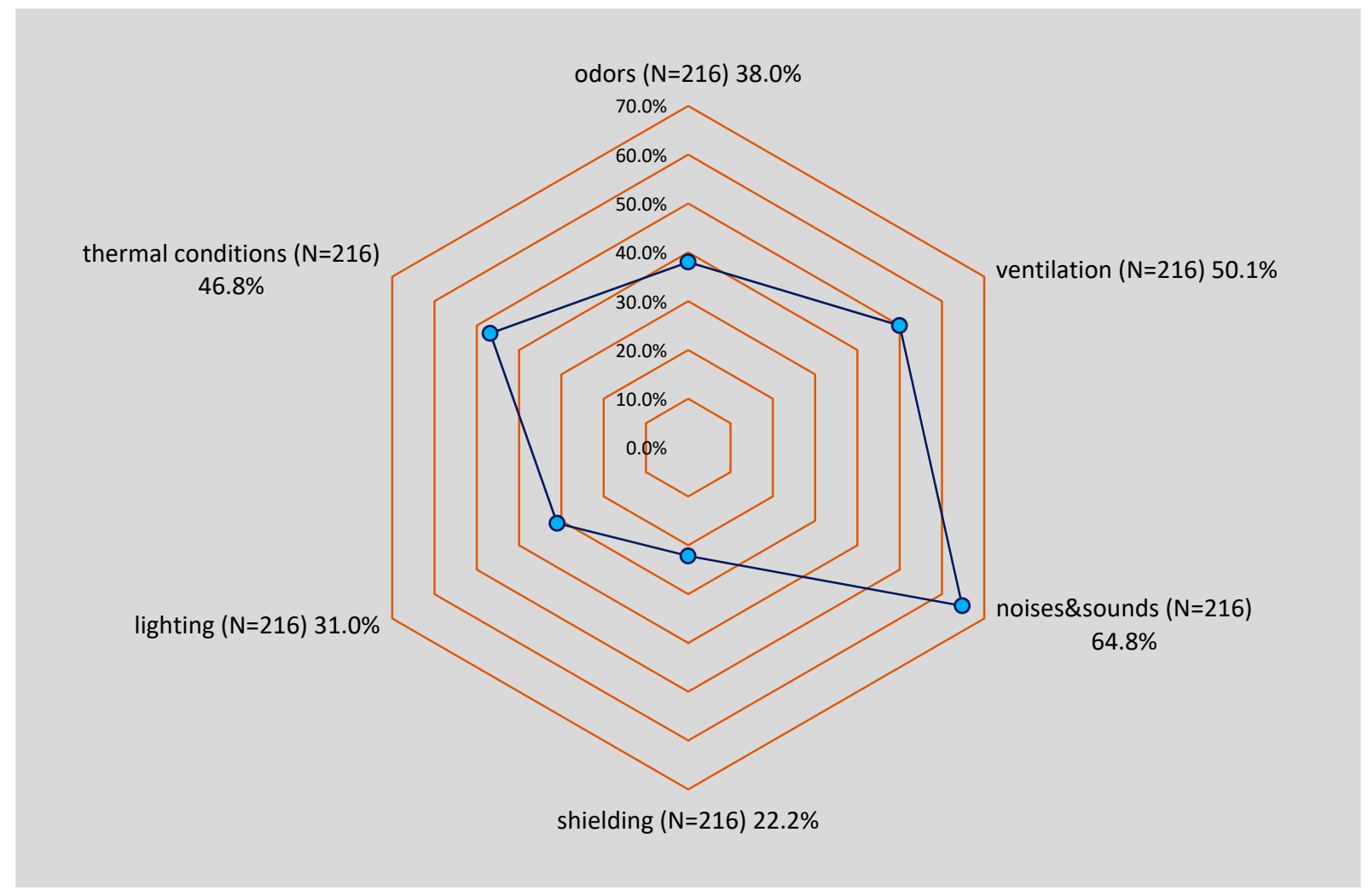

Figure 1. The number of respondents who were dissatisfied with the adjustability of certain IEQ parameters $(N=216)$.

The Parameterized Comfort in Physical Spaces Research Group was formed for a specific research project by researchers in engineering and public health at the University of Pécs (Hungary). This project's initial aims were to explore the underlying reasons for the utility or lack of function and dysfunction of a multi-space office (e.g., lounges). The assessment of the employees' general comfort levels in a given company's office building was also an objective. Within the scope of this project, we formulated the main goals of the present study.

We assumed that office employees might have different IEQ expectations related to their work area and measurable IEQ differences between various parts of the office space. It was also our assumption that office occupants might consider certain IEQ parameters as possible risk factors for their health and that their opinions would differ.

There is a long list of studies from recent years based on similar assumptions. Several of these studies have created maps for depicting the measured differences (e.g., [21-23]). However, these studies focused exclusively on one or two IEQ parameters. In contrast, we 
tried to consider the complexity of comfort sensation in our research and investigate as many IEQ parameters as possible. Moreover, our primary objective was to examine the association between specific IEQ parameters and the comfort sensation of employees. Our goal was to find a viable solution to help office employees improve their self-perceived (subjective) health sensation, related to IEQ parameters. Thus, with these objectives in focus, we developed the concept of the 'comfort map'. The advantage of the comfort map is that occupants can select a preferred workplace based on four different IEQ parameters, which all significantly affect overall comfort levels.

\section{Methods}

\subsection{Research Location}

Data collection, including the comfort survey and the measurements of IEQ parameters, took place in an open-plan office, used by an international telecommunication company in Budapest, Hungary. Participation in the study was voluntary and anonymous. The respondents consented to participate in the survey by filling in the questionnaire. The explanation related to the recruitment and data collection methods were submitted as a part of the Ethics Approval Form. The study was approved by the National Scientific and Ethical Committee of Hungary (TUKEB).

The office building involved in this field study is a seven-floored property rented by the company. The occupants of the office building are employees of the company.

Occupants are expected to spend part of their work hours elsewhere (in other office buildings or at a home office). In the office building, the company uses a desk-sharing system based on the idea that efficiency and comfort at the workplace are not dependent on having one's own desk but instead on having access to different places where particular tasks can be done. Therefore, it is necessary to design additional work zones, such as places for talking on the telephone, places for working without external distractions, places for having informal meetings, places for holding meetings for small groups and creative or project work zones [24]. Consequently, employees do not have their own fixed workstations and are required to reserve a workstation through an online booking system.

\subsection{Comfort Survey}

Since no appropriate standardized instrument was available to explore office occupants' views on the various aspects of their work environment, a questionnaire, the comfort survey, was created specifically for this study. The comfort survey was developed by the Parameterized Comfort in Physical Spaces Research Group. This was justified because our partner company intended to learn more about various aspects of the working environment. We did not find any appropriate standardized instruments that met these needs. The objective of the survey was to assess the comfort levels of the company employees who were the occupants of the office building.

The survey was conducted in November and December 2019. Respondents were asked to fill in the online survey, accessible for occupants on the company's internal network. Participation in the study was voluntary and anonymous. Altogether 216 employees completed the questionnaire. The comfort survey aimed to explore occupants' sense of comfort related to IEQ parameters. Six properties (effects of odors, ventilation, noises and sounds, shielding, lighting and thermal conditions) were considered IEQ parameters.

\subsection{Validation of the Questionnaire}

The questionnaire (see Supplementary Materials) was piloted by ten doctoral students, two managing experts, three lecturers and three researchers (two researchers in architecture and one in public health). The pilot was conducted to review the order, consistency and categories of the newly developed questions. In addition, the company's compliance management and contact person provided feedback on the questionnaire during the pilot study. Following the pilot test, modifications were made to the questionnaire. Four questions considered inappropriate were deleted. 
Minor changes were made to some questions (for example, rephrasing, splitting a question in two, reordering questions). The final questionnaire comprised 37 questions, including 33 multiple-choice and 4 open-ended questions. The questionnaire was prepared in both Hungarian and English.

\subsection{Data Analysis}

To explore respondents' sensations related to IEQ parameters, their satisfaction with IEQ parameter adjustability and the assumed health impacts of IEQ parameters, descriptive analysis was carried out using R v3.6.3 statistical software. Some selected original items of the questionnaire are included in the headers of Tables 1-3.

Table 2. The self-perceived wellbeing of office occupants related to the IEQ parameters of the work environment.

\begin{tabular}{ccccc}
\hline \multirow{2}{*}{ IEQ Parameters } & \multicolumn{3}{c}{ Q9: How Do the Following Properties of the Work Environment (Where You Spend Most of Your Time) } \\
Affect Your Wellbeing and Contentment?
\end{tabular}

Results from primary data collection.

Table 3. Occupants' self-perceived sensation of health related to IEQ parameters in the work environment.

\begin{tabular}{|c|c|c|c|c|c|c|}
\hline \multirow[b]{2}{*}{ IEQ Parameters } & \multicolumn{6}{|c|}{ Q25: How Do You Think Your Health at Your Workplace Is Affected by IEQ Parameters? } \\
\hline & $\begin{array}{c}\text { Very Negatively } \\
(\%)\end{array}$ & $\begin{array}{c}\text { Negatively } \\
(\%)\end{array}$ & $\begin{array}{c}\text { Does Not Affect } \\
(\%)\end{array}$ & $\begin{array}{c}\text { Positively } \\
(\%)\end{array}$ & $\begin{array}{c}\text { Very Positively } \\
(\%)\end{array}$ & $\begin{array}{c}\text { I Can't Decide } \\
(\%)\end{array}$ \\
\hline Odors $(N=216)$ & 11.1 & 17.6 & 43.1 & 11.6 & 11.1 & 5.6 \\
\hline Ventilation $(N=216)$ & 14.4 & 25.5 & 25.0 & 15.7 & 14.8 & 4.6 \\
\hline Noises and sounds $(N=216)$ & 19.9 & 25.9 & 24.5 & 12.5 & 13.4 & 3.7 \\
\hline Shielding $(N=216)$ & 4.6 & 10.6 & 40.7 & 25.5 & 13.4 & 5.1 \\
\hline Lighting $(N=216)$ & 6.0 & 19.9 & 26.9 & 27.3 & 16.2 & 3.7 \\
\hline Thermal conditions $(N=216)$ & 15.7 & 19.4 & 26.9 & 27.3 & 16.2 & 4.2 \\
\hline
\end{tabular}

Results from primary data collection.

\subsection{Measurements of Indoor Environmental Quality}

The measurements related to IEQ parameters were carried out in two phases, with the same methods and equipment. The first phase was conducted in November 2019 and the second phase was conducted at the end of January 2020. The first phase served as a sampling phase, in which a comprehensive investigation focusing on the IEQ parameters of the whole office level was carried out. Based on these results, a typical office environment was selected for the second measurement phase. Figure 2 shows the plan of the office where the measurements were carried out.

This office space was $181.5 \mathrm{~m}^{2}$ in size. It included 43 workstations and was chosen because it was the most typical office work environment in the building. All tested IEQ parameters in the examined office space met the current standards and regulations. The IEQ parameter-related measurements were performed on a regular workday between (9-16 h), on a predetermined date, for all of the individual workstations found in the office. Eleven members of the research group, split into four groups, were involved in the measurements. Each group was responsible for measuring a given comfort parameter. During the measurement, the outdoor temperature was $8{ }^{\circ} \mathrm{C}$ and the humidity was 84 percent. It was a cloudy day. The indoor thermostat was set to $25^{\circ} \mathrm{C}$. At the time of data collection, 19 occupants were present in the selected office space. 


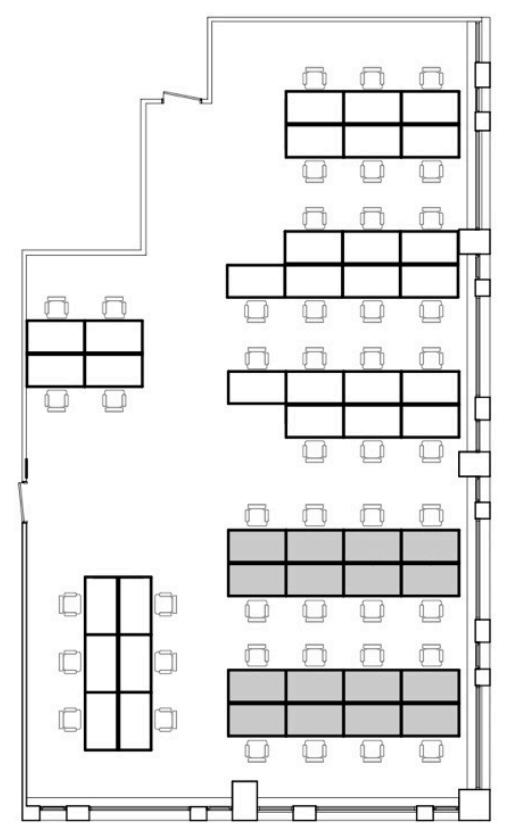

LEGEND:

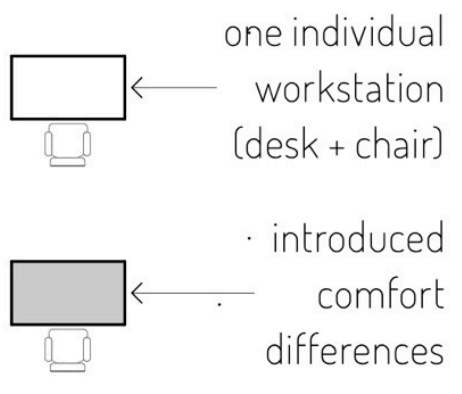

Figure 2. Plan of the office where the measurements were carried out.

The instruments used for the measurements were factory-calibrated. For visual comfortrelated measurements, a KIMO LX 200 Luxmeter (Kimo Instruments Company Ltd, ZA Bernard Moulinet-Rue Koufra, Montpon Ménestérol, France), measuring 0.1-200,000 LUX (Unit of illumination; light emitted per square meter by a light source with a lumen intensity, abbreviated as $1 \mathrm{x}$ ) and 0.01-18585 fc, was used. The total luminous flux incident on the surface was measured for office workstations. The auditory comfort-related measurements were performed with an NTI Excel 2 device (Nti Audio AG, Schaan, Liechtenstein) measuring in the ranges of $0-130 \mathrm{~dB}$ and $20 \mathrm{~Hz}-8 \mathrm{kHz}$, in accordance with the IEC 61672-1 standard. Thermal comfort and air quality-related measurements were performed with a Testo 480 multifunctional measuring device (Kamera Security Ltd, Budapest, Hungary). Short-term (10-30 min) measurements were performed during sampling. For all 43 workstations, air temperature, humidity, air velocity, radiant temperature and $\mathrm{CO}_{2}$ concentration values were recorded. The predicted mean vote (PMV) and predicted percentage of dissatisfaction (PMD) [25] values, plus the effective temperature and the corrected effective temperatures, were also determined during the analysis. Since the measurements were conducted during the heating season, the measurements of the study apply to circumstances when heating is present and air conditioning is not used.

\section{Results}

Based on the data analysis results, at least 3.7 percent of the occupants indicated that one of the IEQ parameters strongly negatively affected their wellbeing (Table 2).

If we combine the negatively and strongly negatively perceived IEQ parameters, more than half of the respondents $(53.7 \%)$ considered office noises and sounds as the IEQ parameter that negatively affected their wellbeing (Figure 3). On the other hand, only 19.9 percent of the occupants perceived shielding to have a possible negative effect on their wellbeing. 


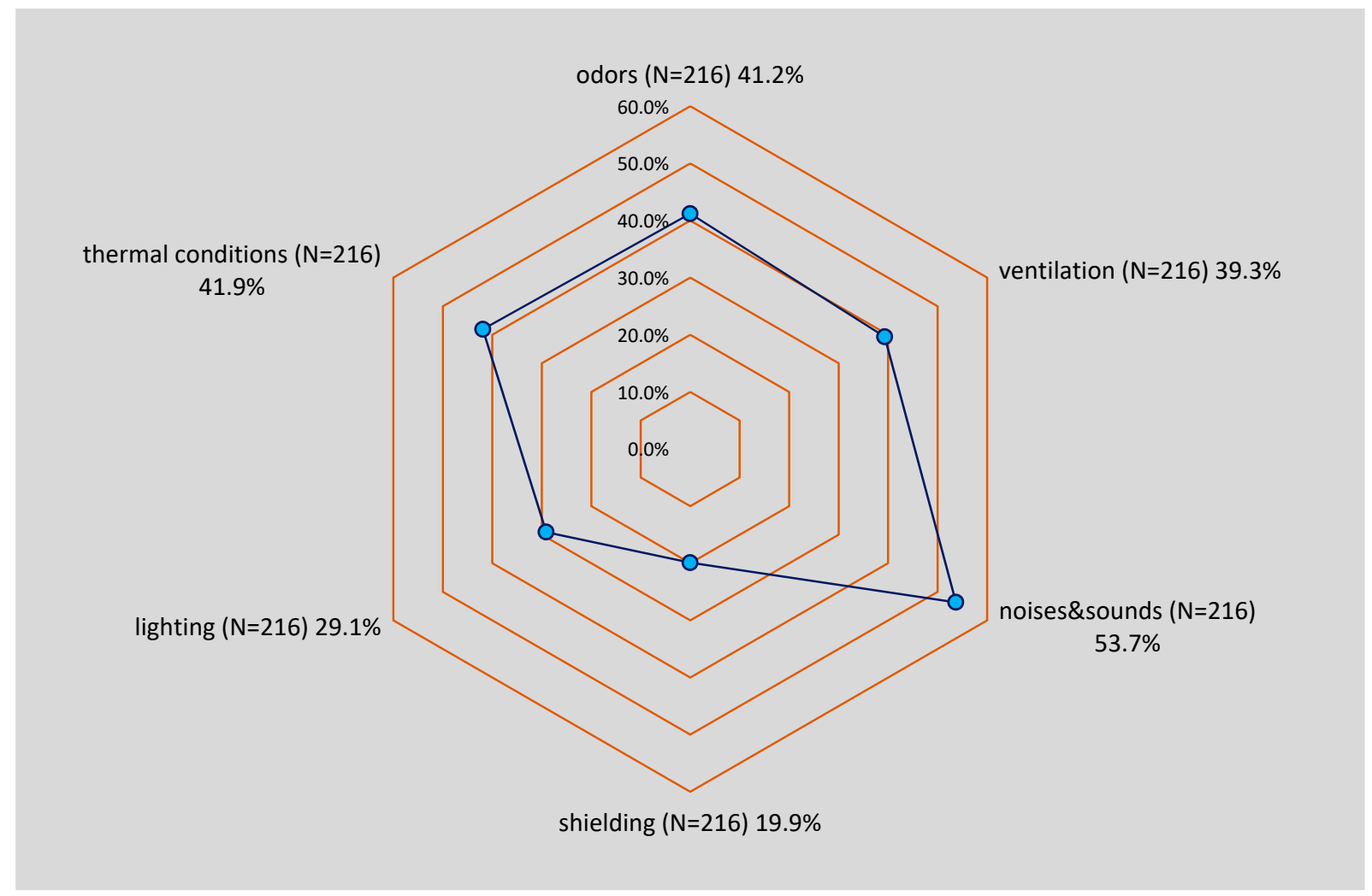

Figure 3. The number of respondents who considered their wellbeing negatively affected by certain IEQ parameters $(N=216)$.

In total, 10 or more percent of the occupants were very unsatisfied with at least one IEQ parameter's adjustability (Table 1).

Almost two-thirds of the respondents $(64.8 \%)$ were dissatisfied with the adjustability of the noises and sounds parameter at the workstations (Figure 1). In addition, half of the respondents (50.1\%) were dissatisfied with the adjustability of ventilation.

Regarding self-perceived sensation of health, at least 4.6 percent of occupants considered the parameter of shielding to have a very negative effect on their health (Table 3).

If we combine the negatively and very negatively perceived IEQ parameters, almost half of the respondents $(45.8 \%)$ considered noises and sounds as the IEQ parameter that negatively affected their health (Figure 4). On the other hand, only $15.2 \%$ of the occupants perceived shielding as a possible risk factor affecting their health.

Taken together, a considerable proportion of the occupants believed that more than one IEQ parameter affected their health and comfort negatively.

The indoor environmental quality measurements showed considerable differences between the different parts of the space in terms of visual comfort, acoustic comfort and thermal comfort (Table 1).

The data in Table 4 shows that there was at least a twofold difference between the lowest and highest values of the measured parameters in the workstations of the open-plan office. This statement was true for all measured parameters. Although the room met all the relevant technical requirements, there were significant IEQ differences within the office space. 


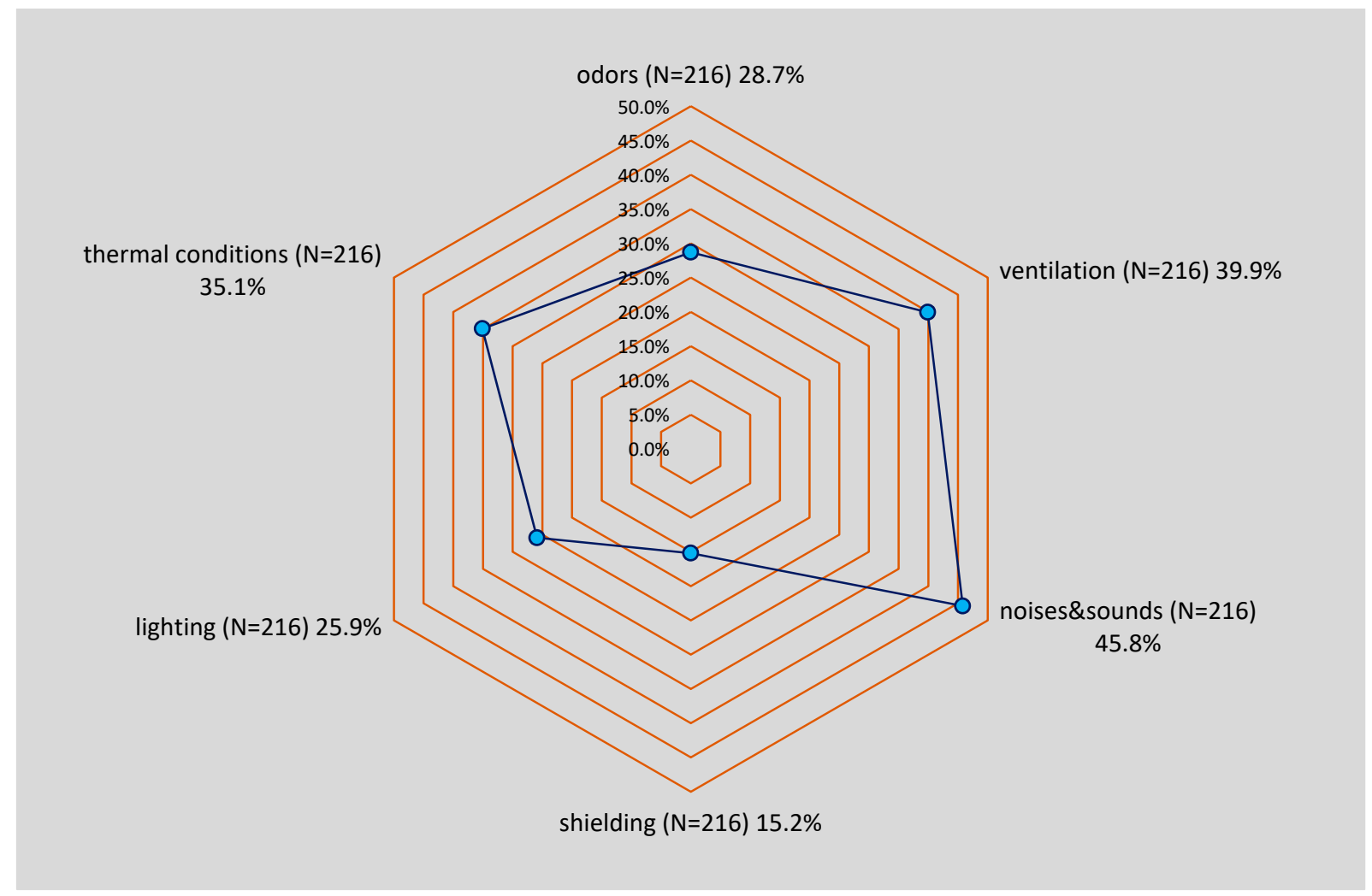

Figure 4. The proportion of respondents who thought that certain IEQ parameters affected their health negatively $(N=216)$.

Table 4. The minimum and maximum values of the measured IEQ parameters.

\begin{tabular}{cccc}
\hline IEQ Parameters & Attributes & Values & Reference Values \\
\hline Visual comfort & Daylight factor (DF) (\%) & $0.7-15.1$ & $\geq 2$ \\
\hline \multirow{2}{*}{ Acoustic comfort } & RT60 (sec) & $0.31-0.56$ & $0.3-0.6$ \\
& $\mathrm{~L}_{\mathrm{A}}(\mathrm{dB})$ & $46.1-49.9$ & 40 \\
\hline \multirow{2}{*}{ Thermal comfort } & PMV & $0.51-1.08$ & see Appendix A \\
& PPD & $10.51-29.74$ & see Appendix A \\
\hline Air quality & $\mathrm{CO}_{2}$ concentration $(\mathrm{ppm})$ & $655-1060$ & 1.000 \\
\hline
\end{tabular}

Results from primary data collection.

Based on the thermal, air, acoustic and lighting differences between the workstations, a comfort map was developed for the investigated office space so that occupants could select their preferred workstations (Figure 5).

The comfort map contains information about the IEQ characteristics of each workstation in an easy-to-understand form by depicting the thermal comfort, $\mathrm{CO}_{2}$, visual comfort and acoustic comfort characteristics of a given workstation on a relative scale. The meaning of the individual icons is listed in the comfort map symbol legend (see Appendix B). The lower and upper limits on the symbols' scales show the minimum and maximum values of the given parameters measured in the given office-space. The intensity of each parameter is presented as the number of colored lines on the scale.

The 'Thermal comfort' symbol indicates the temperature range. The degrees on the scale show the relative differences in temperature within the office's temperature range (not degrees in Celsius or Fahrenheit).

The 'Noise' symbol indicates the range of acoustic characteristics of the office space. The materials used in the office environment determine acoustic comfort. The soundabsorbing and sound-reflecting abilities of the surfaces may be relevantly associated with the work performed. The scale shows the noisiness of a given workstation. Worksta- 
tions with lower noise markings on the scale are better if conversations need to be held (personally or on the telephone).

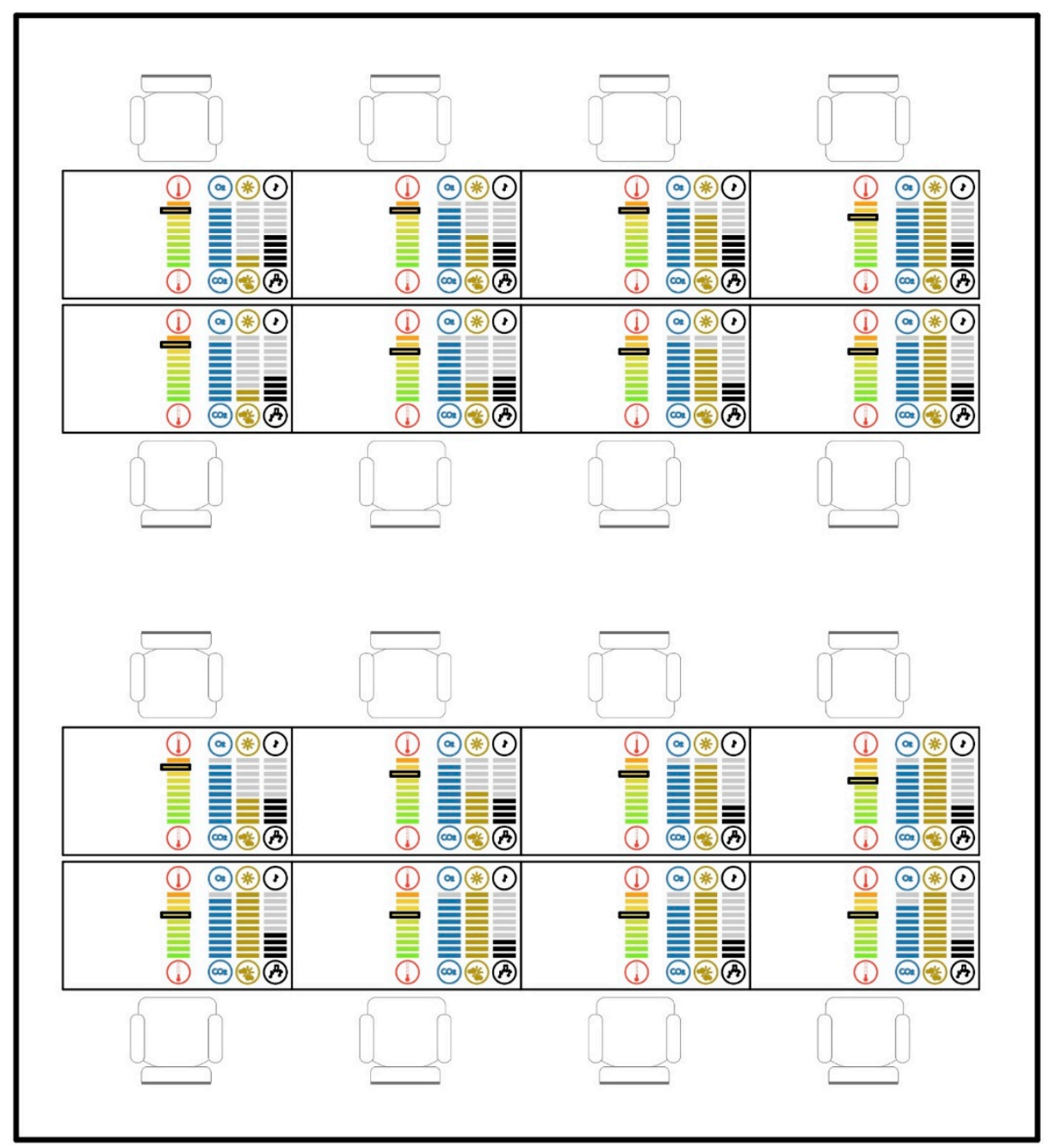

Figure 5. The comfort map.

The 'Lighting' symbol with the scale shows the amount of natural light at the given workstation. Lower markings on the scale indicate darker workstations and higher markings indicate more natural light.

The ' $\mathrm{O}_{2} / \mathrm{CO}_{2}$ ' symbols show the air quality characteristics of the workstation. Higher markings on the scale indicate decreased ventilation and decreased $\mathrm{CO}_{2}$ level at the given workstation.

By having information about comfort parameters, occupants are able to choose the workstation most suited to their health and comfort needs and the type of work they will be doing that day.

\section{Discussion}

Research has shown that the IEQ parameters investigated in our study are considered personal health risks and annoying effects by office occupants [26-28]. In line with these findings, we aimed to develop a possible solution for this phenomenon. The development of our tool, the comfort map, was based on the data from our survey and IEQ measurements. Its objective is to help office employees choose the optimal workstation for their daily tasks and reduce all the adverse IEQ effects of a certain office environment.

Since the comfort map shows the workstation-specific values for thermal comfort, air quality, lighting conditions and acoustic comfort, workstations more suitable for certain 
types of work in terms of comfort can also be determined by occupants. By increasing overall comfort levels, both employee satisfaction and productivity can be enhanced $[29,30]$. Moreover, work satisfaction is affected as well.

Furthermore, applying the comfort map could be beneficial in office spaces where the adjustability of IEQ parameters cannot be technically rationalized or in which rationalization would be very costly. This could help meet occupants' needs by allowing them to select more favorable IEQ parameters for themselves. Therefore, the comfort map could provide the possibility of 'alternative adjustability' of IEQ parameters, which is a particularly relevant aspect of overall comfort levels [31].

It is well-known from practical experience that certain workstations are more popular in an office than others. This phenomenon warrants further research to investigate the reasons underlying this higher demand. Since the comfort map provides an opportunity for characterizing the IEQ differences between workstations, more workstations could be developed with similar IEQ parameters to the most popular workstations. Thus, the number of popular workstations could increase and the chance of employees choosing from only a selected few favorite workstations would decrease.

Besides its inherent possibilities, there are a few limitations to our study. Since the measurements were carried out in the heating season, we do not have data on the IEQ parameters for air conditioning or no heating. These supplementary measurements need to be performed in the future.

Another limitation of our study is the lack of validation of the comfort map. Initial steps have been taken for the validation process. Although the addition of the comfort map into the presently used desk-sharing online booking system of the company has been initiated, the evaluation of the map's utility is planned as the next step in our research program. Therefore, the introduction of the comfort map into daily practice is still in its pilot phase.

Based on our data, it is apparent that most occupants considered noises and sounds to have a negative effect on their health. In order to develop a plan for health-preventive interventions, it is our goal to conduct further measurements regarding this particular IEQ parameter. Since the noise level in a building is mostly evaluated using the A-weighted sound pressure level $\left(\mathrm{L}_{\mathrm{A}}\right)$, we used this method for our measurements. Nevertheless, if noise is produced by activities or sources characterized by a low-frequency contribution, the measurement of $\mathrm{L}_{\mathrm{A}}$ underestimates the degree of the actual disturbance. The limitations of $\mathrm{L}_{\mathrm{A}}$ measurements suggest that we need to augment our measurements with other parameters, such as the speech transmission index (STI). The STI is the most acknowledged standardized parameter for assessing the intelligibility of a spoken message [32]. By measuring the effect of noise, the degree of disturbance can be determined with more accuracy by the comfort map.

\section{Conclusions}

Understanding occupants' preferences and characteristics can help form healthenabling work environments and advance overall comfort levels. Our newly developed comfort map enables occupants to choose the most suitable workstation according to their IEQ and health preferences. The need for more tailored workstations based on parameters other than IEQ may be a possible long-term effect of the COVID-19 pandemic. Over the past year, the use of offices has changed considerably, with many employees working from home offices at least part-time. Although studies investigating these novel circumstances have not been published yet, it can be expected that the number of office workstations has been reduced, and preferences relating to certain workstations may have changed. Some work processes probably still need to be carried out in the regular office-and not home office-environments. With the changing trend in office use and reduced office capacity, occupants are not likely to have their own fixed workstations, and the emphasis may shift towards shared-desk systems in the workplace. However, occupants returning to their offices will most likely require that their employers provide a workplace favorable for 
their health and wellbeing. With the continuation of the COVID-19 pandemic, current investigations are exploring the actions employers are willing to take to protect employees health [33]. In light of these possible changes, our comfort map's relevance is obvious, since the mapping of IEQ parameters can be supplemented with other parameters that jointly influence the development of a healthy and safe work environment and enhance occupants' wellbeing.

Supplementary Materials: The following are available online at https:/ /www.mdpi.com/article/ 10.3390/buildings11060233/s1, Comfort Survey Questionnaire.

Author Contributions: Conceptualization, Á.B. and E.S.Z. and J.G.; methodology, Á.B.; data curation, B.C. and J.G.; investigation, B.C.; writing—original draft preparation, Á.B. and E.S.Z. and É.P. and B.C. and G.M. and J.G.; supervision, G.M. All authors have read and agreed to the published version of the manuscript.

Funding: This research received no external funding.

Institutional Review Board Statement: The study was conducted according to the guidelines of the Declaration of Helsinki, and approved by the Ethics Committee of National Scientific and Ethical Committee of Hungary (TUKEB) (protocol code: 49506-2-/2019/EKU and date of approval: Budapest, $27 / 11 / 2019)$.

Informed Consent Statement: Informed consent was obtained from all subjects involved in the study. Written information on the survey was provided in the first part of the questionnaire. Participation in the study was voluntary and anonymous. By filling in the questionnaire, the respondents have consented to participate in the survey.

Data Availability Statement: Data sharing not applicable.

Conflicts of Interest: The authors declare no conflict of interest. The funders had no role in the design of the study; in the collection, analyses, or interpretation of data; in the writing of the manuscript, or in the decision to publish the results.

\section{Appendix A. Reference Values for PMV and PPD Parameters}

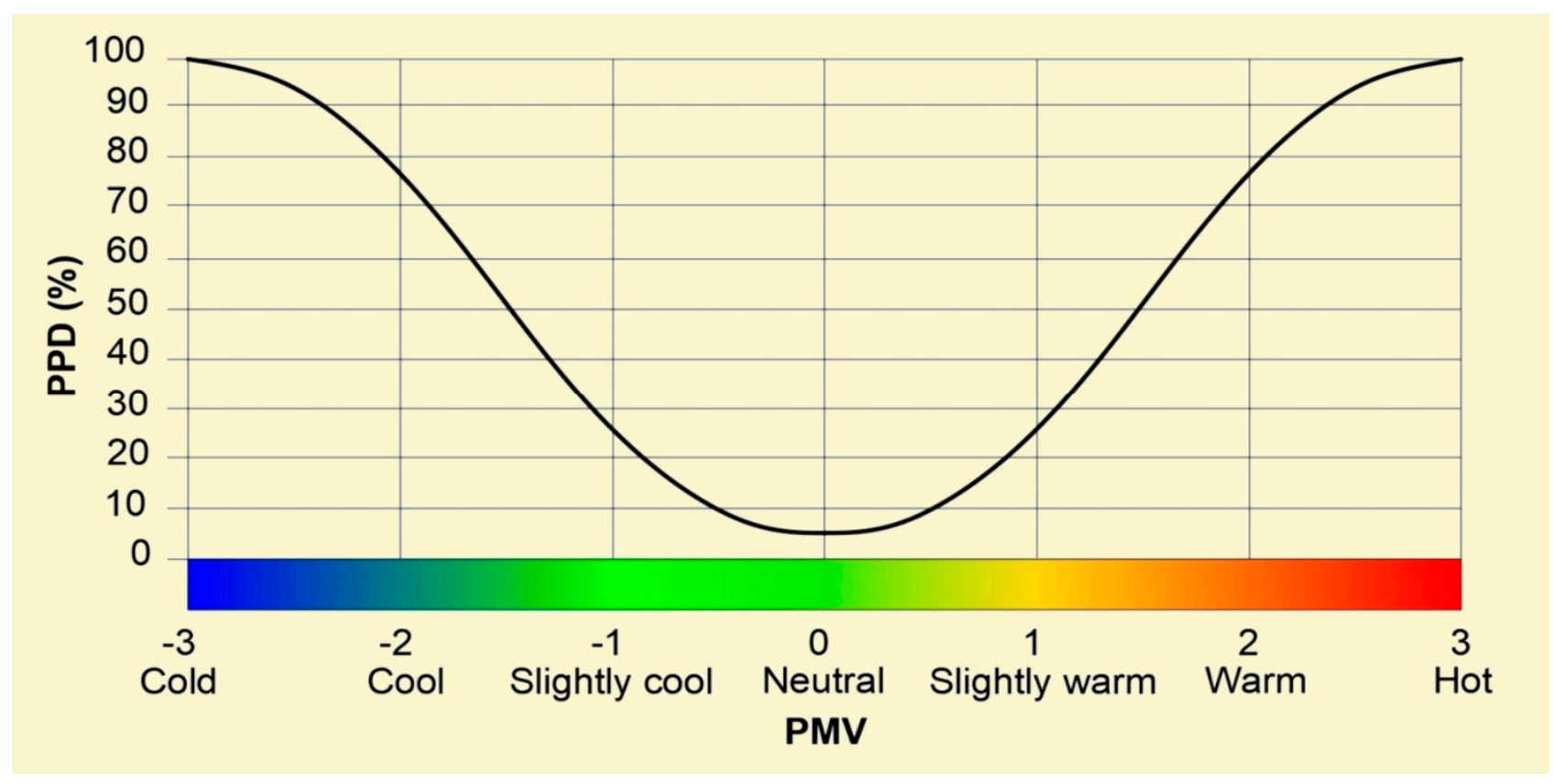

Figure A1. Reference Values for PMV and PPD Parameters. 


\section{Appendix B. Symbol Legend for the Comfort Map}

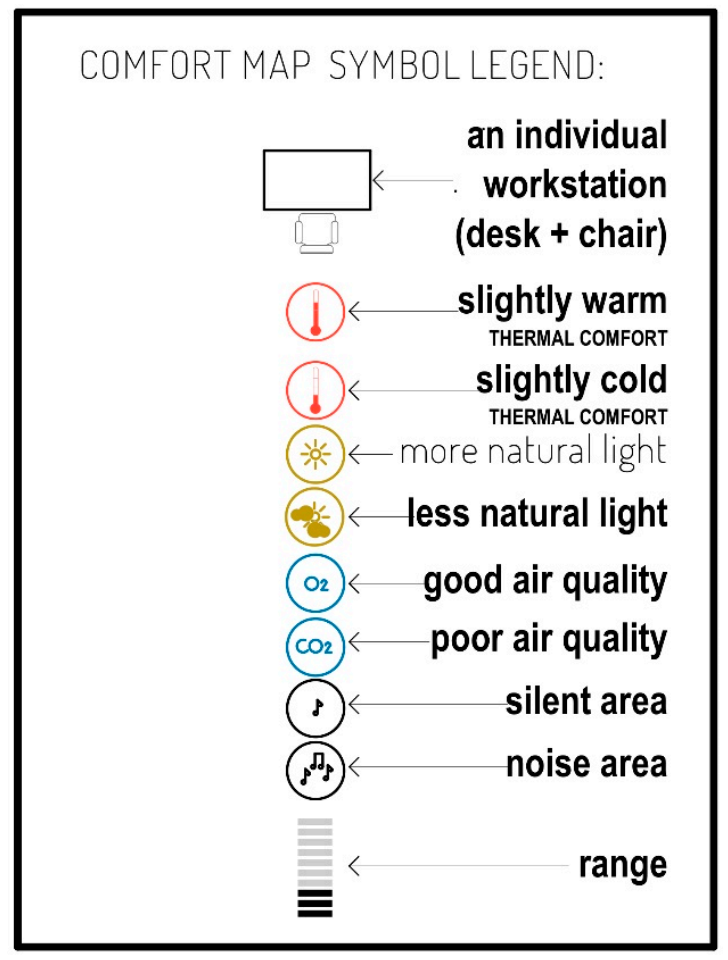

Figure A2. Symbol legend for the Comfort Map.

\section{References}

1. Roelofsen, P. The impact of office environments on employee performance: The design of the workplace as a strategy for productivity enhancement. J. Facil. Manag. 2002, 1, 247-264. [CrossRef]

2. Vimalanathan, K.; Babu, T.R. The effect of indoor office environment on the work performance. Health and wellbeing of office workers. J. Environ. Health Sci. Eng. 2014, 12, 113. [CrossRef]

3. Lamb, S.; Kwok, K.C. A longitudinal investigation of work environment stressors on the performance and wellbeing of office workers. Appl. Ergon. 2016, 52, 104-111. [CrossRef]

4. Šujanová, P.; Rychtáriková, M.; Mayor, T.S.; Hyder, A. A Healthy, Energy-Efficient and Comfortable Indoor Environment, a Review. Energies 2019, 12, 1414. [CrossRef]

5. Partonen, T.; Lonnqvist, J. Bright light improves vitality and alleviates distress in healthy people. J. Affect. Disord. 2000, 57, 55-61. [CrossRef]

6. Wirz-Justice, A.; Terman, M.; Oren, D.A.; Goodwin, F.K.; Kripke, D.F.; Whybrow, P.C.; Wisner, K.L.; Wu, J.C.; Lam, R.W.; Berger, M.; et al. Brightening depression. Science 2004, 303, 467-469. [CrossRef] [PubMed]

7. Lucas, R.J.; Peirson, S.N.; Berson, D.M.; Brown, T.M.; Cooper, H.M.; Czeisler, C.A.; Figueiro, M.G.; Gamlin, P.D.; Lockey, S.W.; O'Hagan, J.B.; et al. Measuring and using light in the melanopsin age. Trends. Neurosci. 2014, 37, 1-9. [CrossRef] [PubMed]

8. Banbury, S.; Berry, D.C. Disruption of Office-Related Tasks by Speech and Office Noise. Br. J. Psychol. 1998, 89, 499-517. [CrossRef]

9. Jones, D.M.; Miles, C.; Page, J. Disruption of Proof Reading by Irrelevant Speech: Effects of Attention. Arousal or Memory? Appl. Cogn. Psychol. 1990, 4, 89-108. [CrossRef]

10. Al Horr, Y.; Arif, M.; Kaushik, A.; Mazroei, A.; Katafygiotou, M.; Elsarrag, E. Occupant productivity and office indoor environment quality: A review of the literature. Build. Environ. 2016, 105, 369-389. [CrossRef]

11. Sundell, J.; Levin, H.; Nazaroff, W.W.; Cain, W.S.; Fisk, W.J.; Grimsrud, D.T.; Gyntelberg, F.; Li, Y.; Persily, A.K.; Pickering, A.C.; et al. Ventilation rates and health: Multidisciplinary review of the scientific literature. Indoor Air 2011, 21, 191-204. [CrossRef] [PubMed]

12. MacNaughton, P.; Pegues, J.; Satish, U.; Santanam, S.; Spengler, J.; Allen, J. Economic. Environmental and Health Implications of Enhanced Ventilation in Office Buildings. Int. J. Environ. Res. Public Health 2015, 12, 14709-14722. [CrossRef] [PubMed]

13. Apte, M.G.; Fisk, W.J.; Daisey, J.M. Associations between indoor $\mathrm{CO}_{2}$ concentrations and sick building syndrome symptoms in U.S. office buildings: An analysis of the 1994-1996 BASE study data. Indoor Air 2000, 10, 246-257. [CrossRef] [PubMed]

14. Jacobs, T.A.; Kler, J.S.; Hernke, M.T.; Braun, R.K.; Meyer, K.C.; Funk, W.E. Direct human health risks of increased atmospheric carbon dioxide. Nat. Sustain. 2019, 2, 691-701. [CrossRef] 
15. Wang, Z.; Zhao, H.; Lin, B.; Zhu, Y.; Ouyang, Q.; Yu, J. Investigation of indoor environment quality of Chinese large-hub airport terminal buildings through longitudinal field measurement and subjective survey. Build. Environ. 2015, 94, 593-605. [CrossRef]

16. Azuma, K.; Ikeda, N.; Kagi, N.; Yanagi, U.; Osawa, H. Evaluating prevalence and risk factors of building-related symptoms among office workers: Seasonal characteristics of symptoms and psychosocial and physical environmental factors. Environ. Health Prev. Med. 2017, 22, 38. [CrossRef]

17. Lukcso, D.; Guidotti, T.L.; Franklin, D.E.; Burt, A. Indoor environmental and air quality characteristics, building-related health symptoms, and worker productivity in a federal government building complex. Arch. Environ. Occup. Health 2016, 71, 85-101. [CrossRef]

18. Feige, A.; Wallbuam, H.; Janser, M.; Windlinger, L. Impacts of sustainable office buildings on occupants' comfort and productivity. J. Corp. Real Estate 2013, 15, 7-34. [CrossRef]

19. 3/2002. (II. 8.) SzCsM-EüM Együttes Rendelet a Munkahelyek Munkavédelmi Követelményeinek Minimális Szintjéről. Available online: https: / / net.jogtar.hu/jogszabaly?docid=A0200003.SCM\&celpara=\#xcelparam (accessed on 19 March 2021).

20. Directive 89/654/EEC—Workplace Requirements. Available online: https:/ / osha.europa.eu/en/legislation/directives / 2 (accessed on 19 March 2021).

21. Rabiyanti; Rahmaniar, I.; Putra, J.C.P. Effect of Acoustic and Thermal Comfort to Support Learning Process in a University. Procedia Eng. 2016, 170, 280-285. [CrossRef]

22. Safranek, S.; Collier, J.M.; Wilkerson, A.; Davis, G.R. Energy impact of human health and wellness lighting recommendations for office and classroom applications. Energy Build. 2020, 226. [CrossRef]

23. Alotaibi, B.S.; Lo, S.; Southwood, E.; Coley, E. Evaluating the suitability of standard thermal comfort approaches for hospital patients in air-conditioned environments in hot climates. Build. Environ. 2020, 169. [CrossRef]

24. Zalejska-Jonsson, A.; Wilhelmsson, M. Impact of perceived indoor environment quality on overall satisfaction in Swedish dwellings. Build. Environ. 2013, 63, 134-144. [CrossRef]

25. ISO 7730:2005 Ergonomics of the Thermal Environment-Analytical Determination and Interpretation Of Thermal Comfort Using Calculation of the PMV and PPD Indices and Local Thermal Comfort Criteria. Available online: https: / www.iso.org/ standard/39155.html (accessed on 2 March 2020).

26. Bluyssen, P.M.; Roda, C.; Mandin, C.; Fossati, S.; Carrer, P.; de Kluizenaar, Y.; Mihucz, G.V.; de Oliveira, E.; Fernandes, E.O.; Bartzis, G.J. Self-reported health and comfort in 'modern' office buildings: First results from the European OFFICAIR study. Indoor Air 2016, 26, 298-317. [CrossRef]

27. Eijkelonboom, A.M.; Kim, D.H.; Bluyssen, P.M. First results of self-reported health and comfort of staff in outpatient areas of hospitals in the Netherlands. Built Environ. 2020, 177. [CrossRef]

28. Al Horr, Y.; Arif, M.; Katafygiotou, M.; Mazroei, A.; Kaushik, A.; Elsarrag, E. Impact of indoor environmental quality on occupant wellbeing and comfort: A review of the literature. Int. J. Sustain. Built Environ. 2016, 5, 1-11. [CrossRef]

29. Foldspang, L.; Mark, M.; Rants, L.L.; Hjorth, L.R.; Langholz-Carstensen, C.; Poulsen, O.M.; Johansson, U.; Ahonen, G.; Aasnæss, S. Working Environment and Productivity. A Register-Based Analysis of Nordic Enterprises. 2014. Available online: http: //norden.diva-portal.org/smash/get/diva2:731771/FULLTEXT01.pdf (accessed on 2 March 2020).

30. Massoudi, A.H.; Hamdi, S.S.A. The Consequence of work environment on Employees Productivity. IOSR J. Bus. Manag. 2017, 19, 35-42. [CrossRef]

31. Hauge, Å.L.; Thomsen, J.; Berker, T. User evaluations of energy efficient buildings: Literature review and further research. Adv. Build. Energy Res. 2011, 5, 109-127. [CrossRef]

32. Caniato, M.; Bettarello, F.; Schmidt, C.; Fausti, P. Assessment criterion for indoor noise disturbance in the presence of low frequency sources. Appl. Acoust. 2016, 113, 22-33. [CrossRef]

33. Yuan, Z.; Ye, Z.; Zhong, M. Plug Back Into Work, Safely: Job Reattachment, Leader Safety Commitment, and Job Engagement in the COVID-19 Pandemic. J. Appl. Pscyhol. 2020. [CrossRef] 